Oliver, J. \& Edwald, Á (in press). Between islands of ethnicity and shared landscapes: rethinking settler society, cultural landscapes and the study of the Canadian west'. Cultural Geographies.

DOI: $10.1177 / 1474474014561576$

\title{
Between islands of ethnicity and shared landscapes: rethinking settler society, cultural landscapes and the study of the Canadian West
}

\section{Jeff Oliver}

University of Aberdeen, Scotland

\section{Ágústa Edwald}

University of Aberdeen, Scotland

\section{Abstract}

This paper reviews and rethinks the study of cultural landscapes in the context of western Canadian settlement history. The historiography of scholarship on the colonial period, across a broad array of disciplines, follows themes central to the study of continuity and change in settler societies, including assimilation, cultural revivalism and transnationalism. Influenced by historical conditions particular to the region, namely the creation of migrant block settlements and a legacy of multiculturalism, research has had a longstanding commitment to an ethnic history paradigm, which tends to orient our understanding of the cultural landscape in terms of what Brubaker and Cooper have called 'identity history'. We argue that by focusing on relationships rather than boundaries, future research on the cultural dimension of settlement might move beyond ethnic history through investigating the possibilities of shared landscapes and communities of practice, built on the back of finding common material solutions to the problems of agrarian life.

\section{Keywords}

Canadian prairies, communities of practice, cultural landscapes, ethnicity, historiography, settler society, shared landscapes 
Oliver, J. \& Edwald, Á (in press). Between islands of ethnicity and shared landscapes: rethinking settler society, cultural landscapes and the study of the Canadian west'. Cultural Geographies.

DOI: $10.1177 / 1474474014561576$

\section{Introduction}

One of the early crucibles for modern cultural diversity was the late nineteenth- and early twentiethcentury landscape of the Canadian prairies. Spurred by the promise of land, economic opportunity and social enfranchisement, a tide of Ontarian, British and American migrants began to colonize the Prairie region from the 1870 s. The incomers set the stage for a new cultural order, precipitating the decline of the fur trade, the dispossession of native lands and the rolling out of a new system of property holding ruled by the grid. Populating the prairies with the 'right class' of people, namely migrants of British descent, proved to be an impossible task and before the nineteenth century drew to a close, government efforts to attract settlers extended to a wider pool, to include not only Americans and Britain's near Northern neighbours, notably Scandinavians, but also those from more exotic parts of the continent: central and eastern Europeans. While immigration policies would eventually regain their more conservative tone, they nevertheless hastened the establishment of a diverse cultural landscape. Many parts of the prairies developed a patchwork of ethnic enclaves or block settlements, the result of sustained chain migration of kith and kin; and less commonly, planned group emigration schemes. If late $19^{\text {th }}$ century colonial policies can be said to have begun a process of social segregation, which in many places saw Indigenous peoples increasingly marginalized to the corners of the settlement landscape, by the mid twentieth century emigration patterns had carved up the recently surveyed checkerboard of townships into a sea of 'cultural islands', which spread all the way from southern Manitoba to the foothills of the Rocky Mountains.

It is the peculiar character of this landscape that sets the Canadian prairies apart from other cultural geographies of settler experience. While broad comparisons can be made, for example, with the patterns of settlement south of the American border, the sheer number and diversity of the migrant communities, combined with extremely different policies of integration - the melting pot in the US and multiculturalism in Canada - has not only served to give the northern prairie region its own historical identity, but also encouraged a disproportionate amount of scholarly attention. ${ }^{1}$ The 
Oliver, J. \& Edwald, Á (in press). Between islands of ethnicity and shared landscapes: rethinking settler society, cultural landscapes and the study of the Canadian west'. Cultural Geographies.

DOI: $10.1177 / 1474474014561576$

rooting of different peoples to particular locales meant that groups as disparate as Ukrainians, Mennonites, Icelanders, and Scots left an enduring imprint, as much on the prairie landscape, as on prairie academia.

It is with these thoughts in mind that the present paper sets out to review the more salient contours of what we might refer to as the cultural history of settlement. Any attempt to deal with this history must acknowledge the complex role of a range of peoples and interest groups, including indigenous peoples, who were effectively resettled within the context of their own cultural islands: Indian Reserves $^{2}$. While not ignoring their contribution to the remaking of the Canadian west, our focus here emphasizes the complex relationships between different immigrant groups, which grander narratives might term 'colonizer' on 'colonizer', that played a more dominant role in altering its social fabric and, consequently, in shaping its historiography. Influenced by prevailing popular and academic paradigms, lines of questioning and theoretical frameworks almost as complex as the history of settlement itself, academics - including historians, sociologists, geographers, and more recently anthropologists (notably historical archaeologists) - have viewed the Canadian west, as a space of assimilation, a source of cultural persistence and a medium of transnationalism. While a number of reviews exist on the scholarship of the region, ${ }^{3}$ limited attention has focused on how disciplinary specialisms have shaped research contributions or how common points of interest have engendered the cultural landscape with particular valences of selectivity. In seeking to highlight the contours of this historiography, we note how the regional immigration history, combined with the legacy of multiculturalism, has tended to favour a form of identity history focused on ethnicity, which through historical processes of reification has served to structure much cultural analysis in the region. Current work on the politics of identity casts doubt on the prioritization of strong forms of identity like ethnicity or nationality, ${ }^{4}$ instead seeing such categories as outcomes of historically contingent social tensions. Reprising earlier calls to establish more holistic studies of the wider landscape ${ }^{5}$ we seek to encourage a more sophisticated engagement with the nature of social life 
Oliver, J. \& Edwald, Á (in press). Between islands of ethnicity and shared landscapes: rethinking settler society, cultural landscapes and the study of the Canadian west'. Cultural Geographies.

DOI: $10.1177 / 1474474014561576$

that allows for other idioms of lived experience and cultural belonging. In particular we argue for research that looks to the possibilities of shared landscapes and communities of practice, which might unsettle the more indelible ethnic histories we have become more accustomed to.

In the first half the paper, we present a brief historical synthesis of thinking on the cultural landscapes of settler society across a range of disciplines. Given the significant challenges of integrating diverse disciplinary histories into a more or less unified field of assessment, rather than undertaking an exhaustive review, we focus on major trends that have defined historiography. Naturally, as with all synthetic overviews of this nature, there a degree of chronological overlap between the different traditions of scholarship, and where possible we attempt to point these out. In the second half of the paper, we examine the principal reasons for the dominance of ethnic history, and present an outline for future work that seeks to decentre it.

\section{Writing the Cultural Landscape}

Concerns with culture have been forefront in the scholarship of the Canadian west since the settlement landscape was rolled out. While earlier generations of thinkers were in thrall to notions of cultural or 'racial purity', the grand experiment of colonisation quickly challenged historians and newly formed social science disciplines to explain the nature of cultural change clearly emergent in the west. ${ }^{6}$ Early writing within this genre noted how the geographical diversity of the continent shaped the pioneering culture of the west. The best known is Turner's influential frontier thesis, which postulated that the most important factor in forming frontier settlement in America was the existence of the frontier itself. As he put it: on the frontier the 'bonds of custom are broken'. ${ }^{7}$ Similar ideas were fermenting north of the $49^{\text {th }}$ parallel. Canada's northern climate was viewed as favourable for producing a nation of 'energy, strength, self-reliance, health, and purity'; ${ }^{8}$ a developing discourse that linked its supposedly harsh environment with the salvation of an Anglocentric value system increasingly under siege. Such scholarship can be viewed as crudely 
Oliver, J. \& Edwald, Á (in press). Between islands of ethnicity and shared landscapes: rethinking settler society, cultural landscapes and the study of the Canadian west'. Cultural Geographies.

DOI: $10.1177 / 1474474014561576$

deterministic by today's standards, typically linking cultural change with singular causal explanations, but it nevertheless set the stage for over a century of discussion and debate.

\section{Nation-Building and Assimilation}

Interest in the geographical dimension of cultural change served to build early research foundations within disciplines like human geography, but in the brave new world of mass immigration, an instrumentalist line of thinking liberated it from grander projects of theorizing and turned culture into a problem to be solved. The dawn of the twentieth century saw a growing strand of thinking focused on the observation that citizenship within the emerging state required a particular type of immigrant, one that shared - or could potentially share - Anglo-Canadian values; foregrounding the arrival of the concept of the ethnic minority into the academy. Policy makers and social commentators were keen to promote quick and total assimilation, prompting a surge of publications on the subject, focusing in particular on the fast growing Prairie Provinces. ${ }^{9}$ The most influential early example is Woodsworth's Strangers within Our Gates. While maintaining a degree of the racial stereotyping of the previous century, Woodsworth framed settler society as a 'heterogeneous mass' and a 'problem' for integration. ${ }^{10} \mathrm{He}$ evaluated different groups according to degrees of Otherness, starting with the most desirable (immigrants from Great Britain), moving on to immigrants who could be assimilated more or less easily (Scandinavians and other Europeans) and finishing with groups he thought were unassimilable to the Canadian ideal (such as the 'Negro' and 'Indian'). The solution was to be found in restrictive immigration policies, unified education and directed settlement: a landscape of cultural engineering.

The emerging discipline of sociology, informed by the pre-eminent Chicago School, helped to pave the way for increasingly rigorous studies into assimilation. ${ }^{11}$ Although typically lacking the racial overtones of more populist views, Anglo-centrism continued to prevail here. Sociologists broadly agreed that there were assimilative forces at work in society that brought ethnic communities closer to the set of core values shared by the dominant group. What these forces were was a matter of 
Oliver, J. \& Edwald, Á (in press). Between islands of ethnicity and shared landscapes: rethinking settler society, cultural landscapes and the study of the Canadian west'. Cultural Geographies.

DOI: $10.1177 / 1474474014561576$

perspective, though 'modernizing' factors, such as increased individualism and secular institutions were thought to play a significant role. Early work in this field across North America underlined the transformative forces experienced by ethnic minorities as they sought to make their way in the New World; ${ }^{12}$ and such ideas were quickly put to use in prairie scholarship. ${ }^{13}$ For example, drawing on a cross-cultural comparative methodology geared to a macro scale of analysis, the Chicago-trained sociologist C.A. Dawson developed a general model of evolutionary change, which documented the slow but inevitable assimilation of block ethnic settlements. While recognizing that relative adherence to ethnic languages, religion and other social institutions suggested that some groups were more (e.g. Catholic Germans) or less assimilated (e.g. Doukhobors) he explained these discrepancies in terms of different stages of assimilation. All would eventually lose their Old World attachments, as common problems were overcome by arriving at common solutions. ${ }^{14}$

By mid-century, however, a series of criticisms began to question the foundations of the assimilation model. Spurred by civil unrest in the 1960s detractors highlighted more clearly than before the fact that ethnic traditions continued to persist and offered suggestions that helped to explain this phenomenon. ${ }^{15}$ Authors such as Gordon began to lay out more complex stages of assimilation, making the notable contribution that it was possible for a group to stall between stages, which helped to explain the continuance of certain ethnic observances. ${ }^{16}$ In Canada, the sociologist Breton reasoned that ethnic survival was largely tied to the maintenance of particular institutions, such as religion, schools and ethnic language newspapers, ${ }^{17}$ findings that were largely supported by prairie scholarship on the immigration of specific ethnic groups, such as the Ukrainians, Jews and Poles. ${ }^{18}$ For example, Anderson interviewed and assessed the level of assimilation of eighteen ethnoreligious communities in Saskatchewan. Focussing on factors such as language retention, religion, and interethnic marriage, he concluded that all ethnic groups tended to 'progressively deemphasise ethnic identification', but that the rate of assimilation in each group was considerably varied due to issues such as the size of block settlements as well as relative degrees of social exclusion. ${ }^{19}$ Even 
Oliver, J. \& Edwald, Á (in press). Between islands of ethnicity and shared landscapes: rethinking settler society, cultural landscapes and the study of the Canadian west'. Cultural Geographies.

DOI: $10.1177 / 1474474014561576$

groups assumed to assimilate quickly, such as Scandinavians, could defy generalizations, as shown in Dahlie's study of private letters, which revealed how some families managed to maintain strong connections with Old World values, even when becoming increasingly integrated. ${ }^{20}$

As the pendulum swung from theories of rapid assimilation towards models that emphasised slower and more complex legacies of interaction, two distinct reactions took shape in the literature. Both were a part of what has been termed the ethnic revival movement, influencing not only academic viewpoints, but also those of immigrant communities. First, a palpable increase in local history writing, concentrating on ethnic communities in particular, was undertaken by amateur historians. Responding to the continuing legacy of groups still evident in the landscape, they produced heavily romanticised, male-dominated accounts of the history of migration, emphasizing the obstacles faced in the establishment of ethnic block settlements, and typically culminating (through the gaze of retrospect) in the inevitable success of their communities. Such narratives praised pioneering ancestors and acted as foundation stories for various ethnic groups who began to celebrate rather than veil their differences. ${ }^{21}$ Although sometimes criticised as limited in objectivity, they have been increasingly acknowledged by academic writers as a rich source on the experience of local communities, with significant implications for the construction of regional identities, many of which continue to be relevant today. ${ }^{22}$ The second reaction was that of the new social history movement.

\section{Social History and the Explanation of Diversity}

The late 1960s and 70s signalled important changes within the historiography of settlement history. Influenced by the new social history movement and developments in the social sciences, scholarly attention moved away from the grander narratives of nation building, with its emphasis on economic progress, political unity and cultural assimilation, towards an understanding of history that recognized the importance of diversity. Rather than treating human behaviour as passively shaped by external forces, the new trend championed a Marxist, human-centred view of 'history from the bottom up' ${ }^{23}$ In the United States, this was reflected in a shift towards studies of gender, class and 
Oliver, J. \& Edwald, Á (in press). Between islands of ethnicity and shared landscapes: rethinking settler society, cultural landscapes and the study of the Canadian west'. Cultural Geographies.

DOI: $10.1177 / 1474474014561576$

power relations within immigrant communities, while in Canada it was accompanied by renewed interest in ethnicity, this time coinciding with the emergent nationalist ideology of multiculturalism and the newly coined 'Canadian mosaic'. ${ }^{24}$ While sociological interest in ethnicity continued unabated, its focus on contemporary society meant increased opportunities for historical disciplines to contribute to the debate, academic history and the relatively new fields of historical geography and historical archaeology included. What these diverse approaches had in common was an explicit interest in the experiences of newcomers and their everyday lives. Assimilation was not abandoned as a concept, but its ethnocentric tones - typical of earlier twentieth century writing - were replaced by an awareness of important aspects of cultural continuity and ethnic resilience in spite of the relentless drive towards modernization..$^{25}$ Notably, this paradigm shift also played a significant role in the establishment of ethnohistory, a field most commonly associated in North America with exploring the previously untold histories of indigenous peoples, though it may also be applied to other minority groups. ${ }^{26}$

Initial forays into social history gravitated towards visible minorities such as the Doukhobors, Hutterites and Mennonites, though other communities, such as Scottish Gallic speakers, were also singled out. ${ }^{27}$ Their starting point was not the problem of diversity. Flipping the obsession with national unity on its head, they positively relished mining personal memoirs, diaries, correspondence and later oral history for evidence of difference, seeking instead to document the unique history of these groups, their migration and settlement patterns and general worthiness to the nation. If early work had something of a marked filiopietistic tone, in common with parallel ethnic revitalization movements, it was cast aside in later research, mainly from the 1990's onwards. No longer feeling the need to prove 'respectability' in the face of Anglo-Canadian Othering, researchers attained a new critical perspective, exemplified especially in studies of Ukrainian communities. ${ }^{28}$ For example, Francis Swyripa studied the stereotypical image of the domesticated Ukrainian Baba (the good wife or mother figure), a role reified by Ukrainian men to mythical proportions, but which ultimately 
Oliver, J. \& Edwald, Á (in press). Between islands of ethnicity and shared landscapes: rethinking settler society, cultural landscapes and the study of the Canadian west'. Cultural Geographies.

DOI: $10.1177 / 1474474014561576$

achieved a form of ironic retribution over male authority figures by becoming the most powerful symbol of Ukrainian identity held by the Canadian public. Her focus on the stuggle of women marks it out as a prime example of social history, one able to provide a much more complex view of internal power structures and competing identities operating within ethnic enclaves. ${ }^{29}$

While historians investigated the experience of ethnic groups, principally through their writings, historical geographers expanded the contribution to social history by explicitly focusing on the spatial dimension of culture, typically by centring analysis on the built environment. Through identifying a cultural imprint from the 'home country', such as settlement patterns or vernacular architecture, and then evaluating its continuity or change over time and space, they demonstrated how ethnic communities adapted Old World cultural norms to new environments. The transition from frontier immigrant society to mainstream Canadian life has been studied through a variety of contexts, including settlement patterns, farm layouts, church architecture and cemeteries, and most prominently through the study of 'folk housing' a field also contributed towards by architectural historians. ${ }^{30}$ From the steeply pitched thatched roofs and white washed exteriors of Ukrainian homes to the gable and shed houses of the Icelanders, historical geographers added to the sociological repertoire of interviews and questionnaires an explicit concentration on the material expressions of cultural identity, and crucially an understanding that such records could, as Lehr puts it, 'serve as a metaphor for cultural change' ${ }^{31}$ (Figure 1 and 2). A significant outcome of this work has been the observation that the maintenance of ethnic patterns seems to be broadly tied to the preservation of key social institutions and their material presence in the landscape. For example, in a comparative study involving Mennonite, Ukrainian, Doukhobor and Jewish settlements, Katz and Lehr found that, despite the development of the modern prairie landscape with its levelling forces of commercial capitalism and government, those groups who resisted assimilative forces were those that placed significant emphasis on religion, evident in the building and maintenance of ethnic churches. $^{32}$ 
Oliver, J. \& Edwald, Á (in press). Between islands of ethnicity and shared landscapes: rethinking settler society, cultural landscapes and the study of the Canadian west'. Cultural Geographies.

DOI: $10.1177 / 1474474014561576$

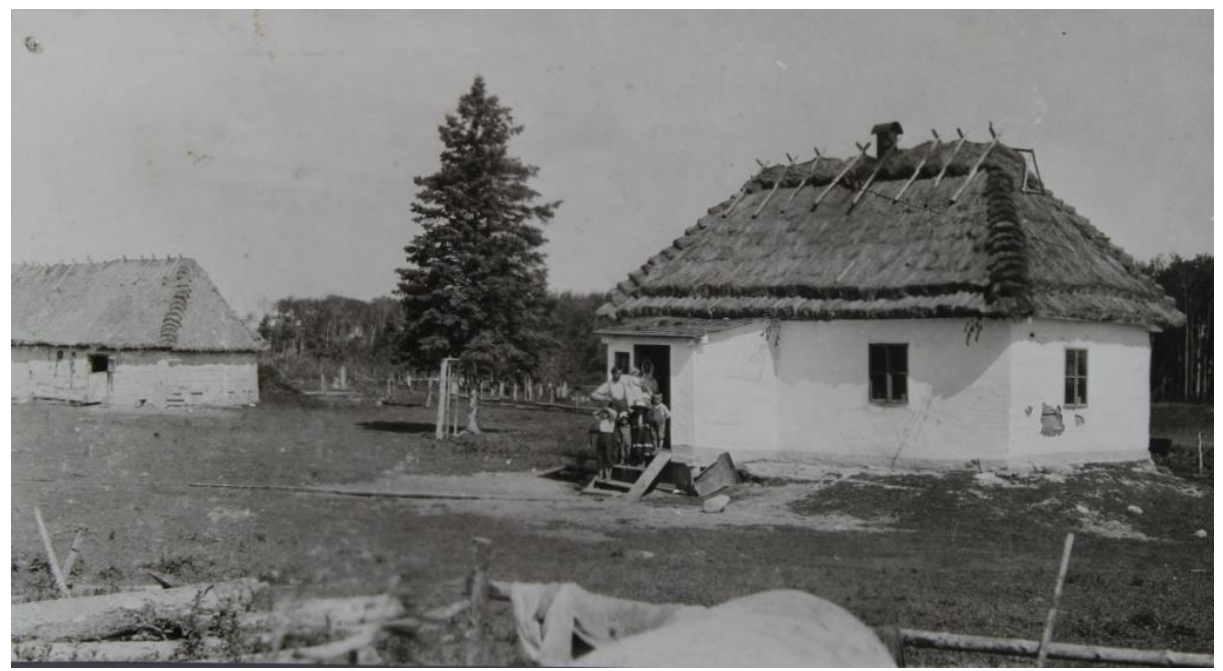

Figure 1. Ethnic architecture in Manitoba as documented in Ledohowski and Butterfield's Architectural Heritage in the Eastern Interlake Planning District (1983). The figure shows a Ukrainian farm in Fraserwood, 1915, illustrating an example of a typical second home in the Interlake region (p. 68) (Archives of Manitoba, Sisler Collection 115 (N9606)). The study of vernacular architecture has played a foundational role in creating ethnic identities across North America. For good overview, see Noble, To Build in a New Land.

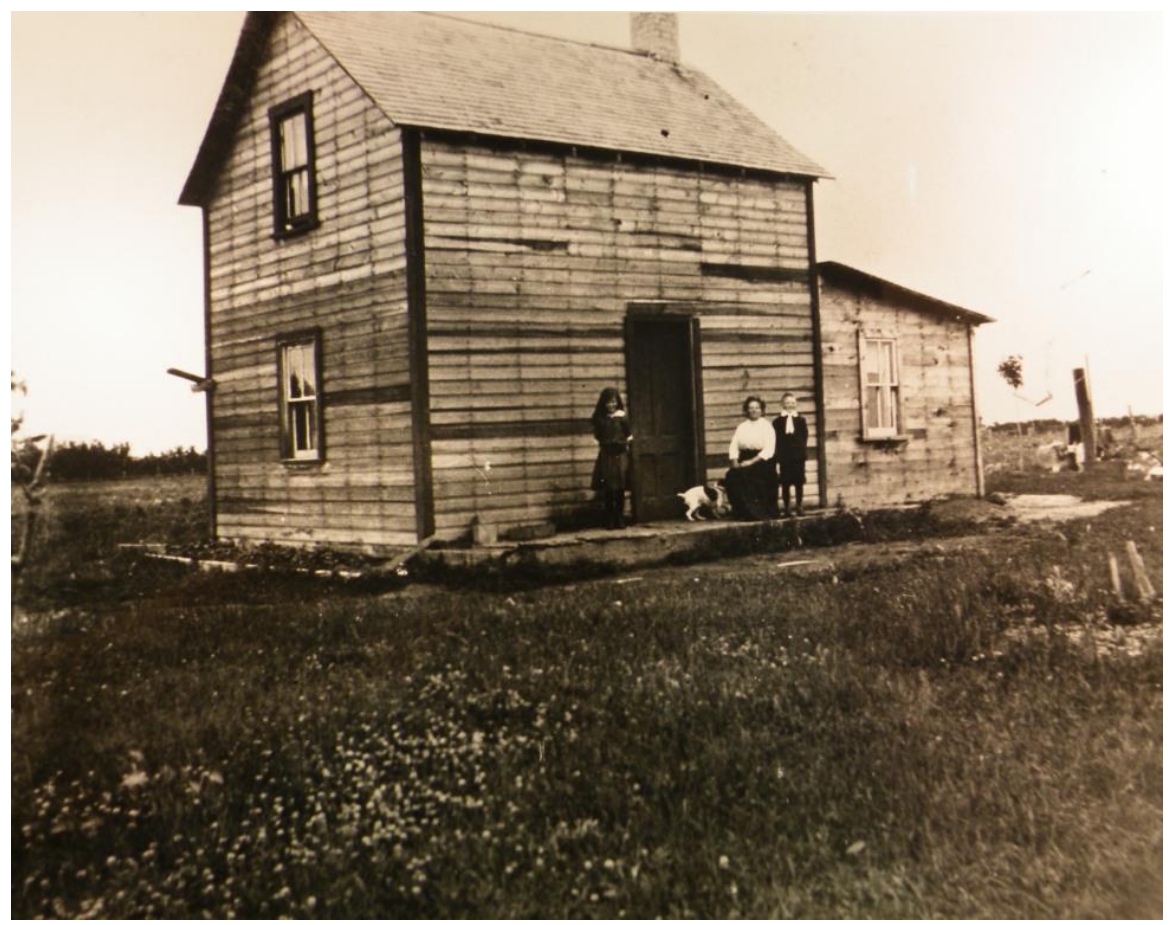


Oliver, J. \& Edwald, Á (in press). Between islands of ethnicity and shared landscapes: rethinking settler society, cultural landscapes and the study of the Canadian west'. Cultural Geographies.

DOI: $10.1177 / 1474474014561576$

Figure 2. A further example of ethnic architecture in Manitoba appearing in Ledohowski and Butterfield (1983). The figure is suggestive of the improvements that Icelandic settlers made to their homes in the Gimli area: wood siding, brick chimney and a lean-to-kitchen (p. 68) (Archives of Manitoba, New Iceland Collection 290 (N11294).

Historical archaeologists have also begun to examine the social history of the settlement period, branching outward from its traditional focus on the fur trade. Taking its cue from the social archaeology of early American life inspired by James Deetz and others, ${ }^{33}$ which emphasized the way that material culture reflected (and among later writers reproduced) cultural worldviews, work in the Canadian west has sought to explore how the experiences of living in a new land impacted on traditional lifeways. Shifting from the broader frames of reference favoured by historical geographers, archaeologists have tended to target the localized setting of homestead sites. In this context, methodological emphasis has typically been placed on comparing artefacts and features for what they reveal about the transformative social and economic realities of the period.

An increasing number of projects, some of which have been instigated by tourism initiatives or, increasingly, heritage management requirements, ${ }^{34}$ have sought to examine the complex relationship between assimilation and cultural continuity. Research across the prairies has examined communities such as the Metis, Doukhobors, Mennonites and Ukrainians as well as those considered idealized citizens, the English, in places like Cannington Manor. ${ }^{35}$ Most archaeology has been concerned with individual settlements; only a few have undertaken comparative work, such as Kennedy's ${ }^{36}$ excavations at sites settled by Mennonites and Anglo-Canadians.

Following Bourdieu's notion of habitus, ${ }^{37}$ Kozakavich's fieldwork at the abandoned village site of Kirilovka in southern Saskatchewan exemplifies the character of this work in its assessment of how Old Word customs, were negotiated in a landscape of new provocations. For instance, Kozakavich 
Oliver, J. \& Edwald, Á (in press). Between islands of ethnicity and shared landscapes: rethinking settler society, cultural landscapes and the study of the Canadian west'. Cultural Geographies.

DOI: $10.1177 / 1474474014561576$

found that aspects of Doukhobor ideology, such as its avowed egalitarianism and its aversion of liquor and meat consumption, were more rhetorical then enacted in practice, as reflected by middens containing alcohol bottles, animal bones and differential quantities of status goods. On the other hand, she has argued that a disproportionate number of large serving vessels indicate that the households had not abandoned communal eating practices in favour of the more commonplace individual place settings, illustrating both adaptability but also resilience in 'maintain[ing] a continuous thread of identity'. ${ }^{38}$

\section{The Cultural Turn}

If social history provided the impetus for a 'bottom up' view of social change, by the 1990s an established postmodernism provided the ammunition for a sustained assault on previously unquestioned givens, notably the master narrative of modernization. It signalled a significant transition from a by-now eroding modernist faith in objectivism to a much greater emphasis on subjectivism. For ethnic histories of migrant communities, this meant a turn away from more static notions of ethnic identity, which depended on objectified cultural givens, towards understandings that are culturally contingent, fluid and multiple, giving rise to what Harzig and Hoerder refer to as 'transnational belonging' ${ }^{39}$ Because the very signifiers of identity were now in question, research priorities shifted to understand how ethnicity was culturally constructed, manipulated and mythologised. Most prominently, this entailed trading in older assumptions about the cultural production of texts, material culture or landscape, from passively reflecting ethnic world views, in exchange for viewing them as ambiguous and historically situated containers of meaning.

A notable recent example is John Lehr's account of the history of the Ukrainian block settlement at Stuartburn, Manitoba, which weaves together the local, regional and global factors influencing every aspect of its development since its origins in the mid-1890s. Lehr questions more static accounts of ethnicity by showing how the identity of Ukranian newcomers was itself fractured and shifting. The early history of the settlement was characterized by considerable social cleavages between Galician 
Oliver, J. \& Edwald, Á (in press). Between islands of ethnicity and shared landscapes: rethinking settler society, cultural landscapes and the study of the Canadian west'. Cultural Geographies.

DOI: $10.1177 / 1474474014561576$

Catholics and Bukovynian Orthodox, seen in the spatial segregation of the settlement, and that occasionally came to a head as open quarrels in Stuartburn's commercial centre. By the $1920 \mathrm{~s}$, a degree of Ukrainian nationalism awakened, founded partly on the development of Ukrainian owned business. Significantly Lehr paints a picture of competing internal and external interest groups, and in doing so he challenges more traditional scholarship that denies or downplays the heterogeneous nature of ethnic groups. ${ }^{40}$

The cultural turn has covered significant ground with respect to the existential nature of social relations and its inherent conflicts and reworkings of the social order. Drawing on concepts such as the 'invention of tradition' ${ }^{41}$ and 'imagined communities', ${ }^{42}$ authors such as Swyripa, Loewen and Friesen ${ }^{43}$ have reminded us that ethnicity does not pre-exist social experience but that it is bound up with the processes of inhabiting a landscape; an ongoing process that has significantly impacted the creation of heritage agendas. Swyripa's multi-generational analysis of ethnic landscapes across the Prairie Provinces, demonstrates how churches, cemeteries and monuments play a central role in community commemoration and the cultivation of ethno-religious group consciousness. In particular she stresses the performative and imaginative nature of ethnic revitalization, such as Icelandic festivals in Gimli Manitoba, which are central to her argument. Eschewing core attributes as indexes of group membership, Swyripa's notion of ethnic identity is a pliable concept, frequently renegotiated and reinvented, allowing for the continuation of ethnic affiliations that both afford and resist assimilation. ${ }^{44}$

\section{Beyond Ethnic History?}

The recognition that ethnicity is unstable, tied to social practices that are themselves fluid, heightens the importance of other kinds of social relations. However, in contrast to the current appeal towards studies of ethnic identity with its varied and complex manifestations of difference, much less attention has been paid to social arenas that cross these boundaries. Historians such lacovetta, 
Oliver, J. \& Edwald, Á (in press). Between islands of ethnicity and shared landscapes: rethinking settler society, cultural landscapes and the study of the Canadian west'. Cultural Geographies.

DOI: $10.1177 / 1474474014561576$

Loewen and Perin have called for research that focuses on interethnic relations, ${ }^{45}$ but few have taken up this challenge. Employing the anthropological notion of 'webs of significance' Lowen and Friesen provide a nuanced analysis of interethnic relations within the small to medium sized cities of the prairie provinces, places which were at least as ethnically diverse at the beginning of the twentieth century as Canada's larger cities were by the end of it. ${ }^{46}$ Within centres like Saskatoon and Winnipeg, social ties that encouraged coherence within household and religious institutions were also those that allowed newcomers to gain entry into the wider community, encouraging a bewildering variety of border crossings, contact and hybridity. More atypical still are studies focusing on rural interethnic relations. Stambrook and Hryniuk's research on early twentieth-century relationships between ethnic Ukrainians and Poles of Galician origin and Eyford's work on late nineteenth century Icelandic interactions with neighbouring Cree and Ojibwa are notable exceptions. Debunking popular myths about ethnic isolationism and interethnic antagonism, they found interesting levels of cooperation in certain contexts: people of different ethnic affiliations often settled next to each other, intermarried and learned each other's language. ${ }^{47}$

Nevertheless, even as research begins to seriously reconsider the ways in which ethnically defined communities interacted with others, and in so doing changed the conditions of their existence, other issues remain unexamined. The fact that ethnic identities are assumed to be firmly located prior to other kinds of social relationships (indeed the very concept of interethnicity can engender this kind of thinking) points to something deeper within the culture of academia and society more broadly.

Two challenges in particular currently limit the scope of research into the cultural landscape of the Canadian west:

1. The historical proliferation of Othering non-English speaking newcomers during the settlement period, broadly from the 1870 s to the middle of the twentieth century. 
Oliver, J. \& Edwald, Á (in press). Between islands of ethnicity and shared landscapes: rethinking settler society, cultural landscapes and the study of the Canadian west'. Cultural Geographies.

DOI: $10.1177 / 1474474014561576$

2. The subsequent objectification of cultural difference as ethnicity exemplified by the emerging ethos of multiculturalism from the middle of the twentieth century onwards.

As scholars of colonialism have pointed out, 'Indigenous peoples', 'Native Americans' and 'First Nations', were not meaningful social categories pre-existing colonization, rather they coalesced as lived identities at the sharp end of colonial processes of discrimination and management. ${ }^{48}$ Indeed, it should be pointed out that such labels hide an incredible amount of diversity, from divisions of language and culture to political affiliations and kinship, categories that are themselves permeable and apt to change. It should therefore come as little surprise that similar forms of Othering are lurking behind the continued emphasis on ethnicity and difference among incoming settler groups, a process which Pearson identifies as ethnification. ${ }^{49}$ Ethnification refers to the subordination of minority groups by dominant forces in society through both discursive and material practices - even by other minority groups in thrall to local power structures. Once taken up within the broader social discourse of settler society, what were once only words gained hard currency, in so far that they became labels used by minorities themselves in contexts where self-determination was to a significant degree shaped by the limitations imposed by society. A well-known example is seen among 'Ukrainian' migrants, who's 'Ukrainianess' was more a product of internalizing process of Othering than it was a category with social efficacy in their eastern European homeland ${ }^{50}$ As John and Jean Comaroff argue the substance of this kind of identification 'as contrived from both within and outside, is inevitably a bricolage fashioned in the very historical process which underwrites their subordination' ${ }^{.51}$

The creation of the ethnic Other was a complex process that obtained purchase in particular historical contexts. As the rhythms of everyday life brought people of varied backgrounds into different forms of interaction, settlers acknowledged various levels of cultural and linguistic difference, ranging from jocular discussions about heavily accented English to outright racism based on differences as wide ranging as religious norms, settlement practices or even hygiene. Some 
Oliver, J. \& Edwald, Á (in press). Between islands of ethnicity and shared landscapes: rethinking settler society, cultural landscapes and the study of the Canadian west'. Cultural Geographies.

DOI: $10.1177 / 1474474014561576$

distinctions were momentary distractions, others longer-lasting with more significant consequences. However, it was the institutionalization of ethnicity to the level of discourse that served to legitimize and catalyse interest in ethnicity. With increasing numbers of European immigrants enticed from the continent after the turn of the twentieth century, a flood of reactionary literature was produced on the subject of non-Anglo immigration. It began with crude racial profiling based on the immigrants' perceived suitability for the dominant model of nationhood, but was soon taken up within the more respectable circles of social science and government. While cultural anthropologists focused on 'Indians', sociologists and others turned their attention toward the non-Anglo-Canadian element within the settlement landscape. In this context, we cannot ignore the efficacy of ethnographic surveys and mapping of 'typical areas,' commonly undertaken by sociology graduate students in establishing the very orderly boundaries of ethnicity. ${ }^{52}$ Consider how the thick bold lines used in a range of cartographic material have helped to give a level of fixity between people and place never before imagined (Figure 3). At the same time, branches of the Canadian government began increasingly to produce and use data on the ethnic makeup of the country, such as the Census of Canada, initiating a century-long attempt to classify, manage and solve the 'problem of Canadian diversity'.53 
Oliver, J. \& Edwald, Á (in press). Between islands of ethnicity and shared landscapes: rethinking settler society, cultural landscapes and the study of the Canadian west'. Cultural Geographies.

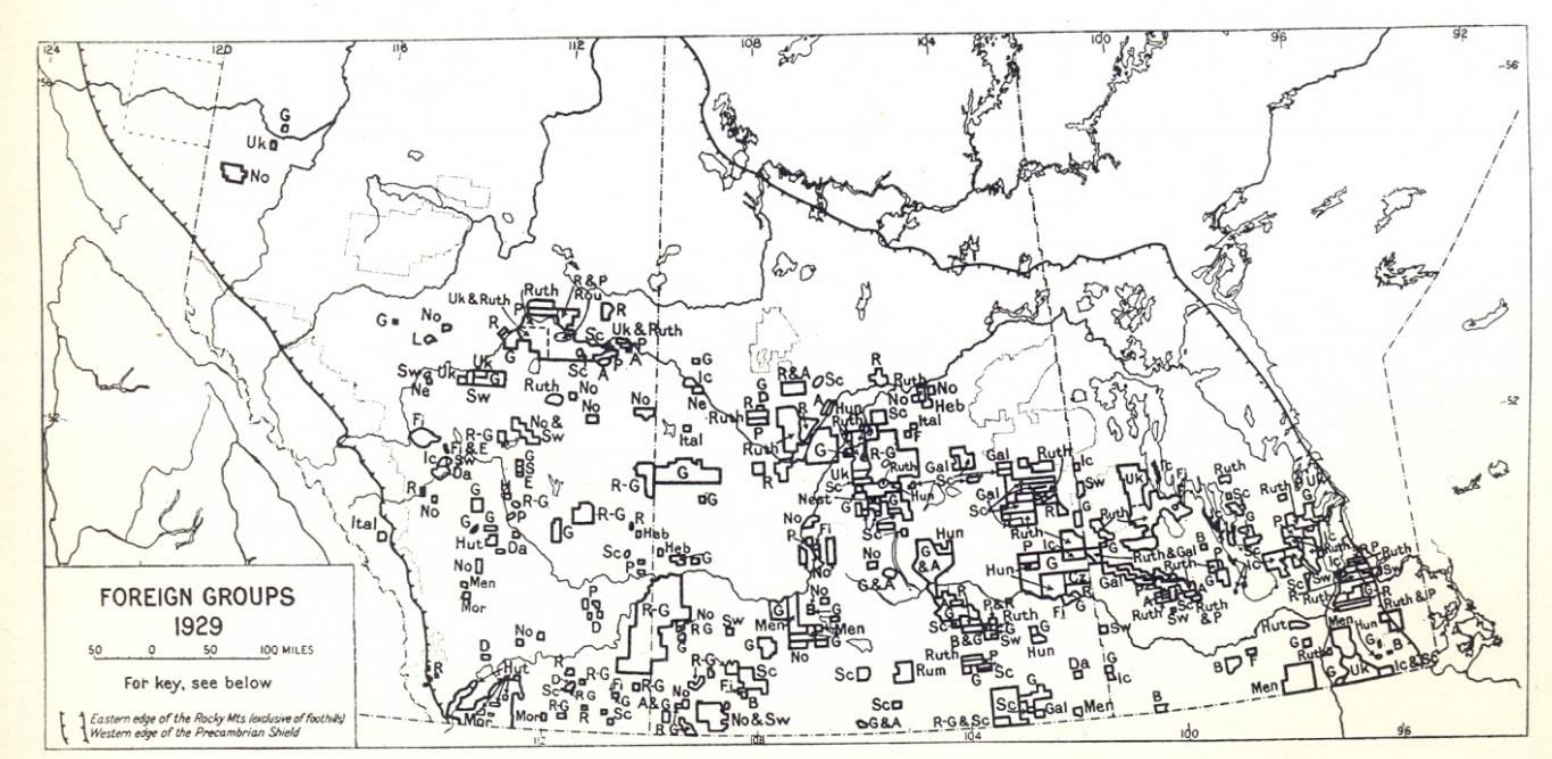

Fio 1-Fortices and languages. Key to symbols: A, Auc. A, Austrians, B, Belgint, Ices, Icelanders; Ital, Italians; L, Letts; Men, Mennonites; Mor, Mormons; Ne, Negroes; Nest, Nestorians (“Assyrians"); No, Norwegians; P, Poles; R, Russians; Rum, Rumanians; Ruth, Ruthenians; S, Swiss; Sw, Swedes; Sc, Scandinavians (undifferentiated); Uk, Ukrainians.

Figure 3. The orderly boundaries of ethnicity. From C.A. Dawson's Group Settlement: Ethnic Communities in Western Canada 1936, p. iv.

If the practices of social scientists and government departments helped to provide a new degree of authority to demographic categories, it was the development of the idea of multiculturalism, followed much later by its official adoption as government policy in the 1970s, that made ethnicity a mass-consumed reality. As Richard Day has cogently argued, the evolution of the 'multiculturalist origin myth', based partly on an understanding of Canada's geographical and ideological space as having always been multicultural, was unveiled as the foundation for a national unifying edifice, though one partial to Anglo-Canadian values. The wheels of Canadian bureaucracy began to turn out a range of communications, the main function of which was not only to colonize minds to accept certain principles of the dominant social order, but also to preserve particular symbols of Otherness, so that they were seen as permissible, even desirable. ${ }^{54}$ As a state-sanctioned ideology, the proliferation of local ethnic revitalization movements throughout the Canadian prairies around this time should be no wonder (see volumes in the Canada Ethnica series, funded by the federal government to celebrate Canada's centennial in 1967); and while the postmodern-fuelled cultural 
Oliver, J. \& Edwald, Á (in press). Between islands of ethnicity and shared landscapes: rethinking settler society, cultural landscapes and the study of the Canadian west'. Cultural Geographies.

DOI: $10.1177 / 1474474014561576$

turn helped to train a more critical eye on cultural and ethnic identities - notably making the important point that such identities are not static but fluid - with 'identity history' all the rage, it has also helped to fetishize them, producing what Brubaker and Cooper have referred to as an 'identity crisis'.$^{55}$ It not surprising then, that with an emphasis on multiculturalism came an almost-insistent focus on the ethnic histories of individual groups. ${ }^{56}$ This in turn has, as Loewen puts it, 'deemphasized border crossings, inter-ethnic relations, and common institutions within a pluralistic countryside'. ${ }^{57}$

\section{Towards rethinking the cultural landscape}

How might the study of cultural landscapes in the Canadian west be incorporated into a broader understanding of human social relations capable of transcending the worrying essentialisms of the ethnic history paradigm, while taking seriously the social tensions of ethnification. The challenge is both theoretical and methodological. Below we outline a three point proposal that attempts to address the variability of the settlement experience. This includes i) the examination of the ways in which social relationships are grounded in certain practices; ii) an emphasis on the conditioning and enabling properties of material engagement; and iii) increased stress on comparative and multi-sited approaches. Building on recent work that accepts the instability of ethnic boundaries, the objective is now to question when and if the boundaries are even relevant. This involves moving from the assumed frame of ethnohistory, where all history is organized around an ethnic point of view, to one that captures a lived-sense of the shifting issues that gave definition to settler society within different spatial and temporal registers.

\section{Grounding ties that bind and lines that divide}

One of our principal contentions is that the boundaries that serve to define communities, whether these characterize dominant groups, institutions, genders, ethnic minorities, or some other social formation, are themselves contingent, depending on a variety of issues that come into focus at 
Oliver, J. \& Edwald, Á (in press). Between islands of ethnicity and shared landscapes: rethinking settler society, cultural landscapes and the study of the Canadian west'. Cultural Geographies.

DOI: $10.1177 / 1474474014561576$

particular historical moments. ${ }^{58}$ While we broadly follow the cultural turn and its insistence on fluidity and on rejecting settled identities, we also wish to make a particular stand, as Doreen Massey does, about the need to clearly identify contexts where temporary stabilities are achieved what we might call provisional objectifications - in the way people relate to each other and to things, which ultimately suppress or highlight different kinds of social distinctions..$^{59}$ In other words, sometimes ethnicity mattered, and sometimes it did not; other issues served to foreground social interaction.

As highlighted in our review, previous research has tended to emphasize the unique character of newcomers who stood out from the crowd. And there may well be good reasons for doing so: from the point of view of a history from-the-bottom-up, it has helped to problematize modernizing and nationalist discourses. Indeed, we are much richer for understanding the role that institutions, like language and religion, played in buttressing aspects of cultural continuity among certain minority groups within a political environment striving towards integration. Within these contexts, lines of ethnic difference could be thrown up in sharp relief, as in 1940s Rossburn, Manitoba, where 'BritishCanadian' and 'Ukrainian' cultural misunderstandings helped to temporarily police the boundary between these respective groups. ${ }^{60}$ However, because living in a new land was also bound up with new entanglements, created as newcomers formed relationships with new environments, people and things, it provided the fabric for what Harrison has called shared landscapes. ${ }^{61}$ The idea of shared landscapes entails the notion that people from different backgrounds may participate in mutual histories of working and living together.

On the one hand, shared histories can highlight both common and dissimilar viewpoints about shared experiences, as shown by Harrison's own research on colonial Australia's multicultural pastoral industry, where indigenous and white ranchers formed shared attachments to place. However, on the other hand, we propose that it may also be conceived in terms of what Lave and Wenger (1991) had in mind when they introduced the idea of a community of practice. Influenced by 
Oliver, J. \& Edwald, Á (in press). Between islands of ethnicity and shared landscapes: rethinking settler society, cultural landscapes and the study of the Canadian west'. Cultural Geographies.

DOI: $10.1177 / 1474474014561576$

practice theory more broadly, the concept builds on the premise that because people participate in different kinds of activities with others, at multiple levels, their membership within such mutual engagements may entail the creation of a community of practice. ${ }^{62}$ Wenger outlines three characteristics of a community: mutual engagement, a shared project, and the development of a repertoire of practices mutually intelligible among members. Significantly, the concept emphasizes the potential for people with different affiliations (institutional, economic, ethnic etc.) to be part of a knowledge or skills-based collective that sets out, in concert, to undertake a particular set of objectives..$^{63}$

We might expect shared landscapes and communities of practice to emerge within the boundaries of ethnic groups, such as Hutterite colonies; now we must also recognize contexts where they may crosscut and therefore deemphasize such lines of demarcation. Examples are known from studies of cultural entanglement, associated in particular within multicultural cites and delimited spaces of capitalist production, where new social and economic alignments may serve to depress ethnic divides in favour of collective markers of belonging. ${ }^{64}$ The settlement landscape of the Canadian prairies also afforded a range of opportunities to interact with 'outsiders', creating conditions for new shared understandings and forms of social distinction that cut across the grain of expectations. For instance, although many Doukhobors lived a relatively circumscribed existence and could be treated as anthropological Others, it was not uncommon for them to work as wage labourers on threshing or railway work crews, where they played down aspects of their faith, such as vegetarianism ${ }^{65}$, as a means of 'fitting in'. It is within such contexts of practice that we must begin to document and theorize the development of shared codes and or idioms of co-existence. Even if these were only short lived, they speak to largely hidden histories of social life with their own situated 'cultural logics' that could operate beyond the familiar boundaries of block settlements. 
Oliver, J. \& Edwald, Á (in press). Between islands of ethnicity and shared landscapes: rethinking settler society, cultural landscapes and the study of the Canadian west'. Cultural Geographies.

DOI: $10.1177 / 1474474014561576$

\section{Material Entanglements}

Locating spaces and temporalities of shared interaction can be challenging. Fortunately, developments within material culture studies, particularly its emphasis on the agency of objects, ${ }^{66}$ allow additional insights. As previously mentioned, the study of material culture is well-represented within Canadian settlement studies by historical geographers and historical archaeologists, a dominant focus being the tangible imprints that newcomers left as a mark of their dwelling: everything from portable artefacts to built environments constitute elements of the cultural landscape. While this work has its place, notably for charting the transmission of cultural traits from the Old Country to the new, research across the social sciences and humanities has recently called for a more critical engagement with material culture. ${ }^{67}$

These approaches shift the debate from recognizing material culture as a text to be read to accepting the agency of material culture in shaping social configurations and their relational meanings. Taking the observations gleaned by the cultural turn as their starting point, that the meaning of material objects can be renegotiated in different social contexts through the agency of subjects, they take it one step further to show how material culture was not only a bearer of potentially contested meanings, but also had the ability to act upon or influence situations. Under the banner of what some have referred to as the 'material turn', ${ }^{68}$ an agency of things is possible insofar as people are always physically enmeshed within particular material realities, which go on to exert influence on the kinds of choices people can make and the values they hold. From a broader landscape perspective it helps us to recognize, as Barbara Bender does, that 'human interventions are done not so much to the landscape as with the landscape, and what is done affects what can be done ${ }^{69}$.

For example in the Icelandic block settlement of Argyle, in southern Manitoba, nearest neighbours particularly established ones - were vital sources of know-how to negotiate the ins and outs of living in a new land. Where situations permitted, neighbourly relations could spur new aspects of reciprocity, some with enduring material outcomes. Architectural guides to the province detail 
Oliver, J. \& Edwald, Á (in press). Between islands of ethnicity and shared landscapes: rethinking settler society, cultural landscapes and the study of the Canadian west'. Cultural Geographies.

DOI: $10.1177 / 1474474014561576$

vernacular designs common among its Icelandic settlers. This usually included frame-built one-and-ahalf-story gable and shed houses, and simple gabled barns. ${ }^{70}$ However, within the growing Argyle settlement there existed a more complicated architectural legacy including frame-built, Second Empire-inspired homes with mansard roofs (Figure 4), stone-built houses, and occasional 'Ontario Style' barns; architectural forms introduced by their Ontarian neighbours ${ }^{71}$ (Figure 5). Marriage facilitated cross-cultural connections to a degree, but communities of practice were further encouraged on the back of what lan Hodder refers to as established material dependencies, ${ }^{72}$ such as increasing reliance on mixed farming, which created common concerns and common responses to local agrarian, economic and political issues. Within such contexts, shared building styles or agricultural practices are not so much ethnic indicators; rather, as Gosden puts it, they 'set up universes of their own into which people need to fit' ${ }^{73}$ Such instances remind us that the domain of culture transcends its more simplistic equation with identity markers, and encourages us to think about culture as process, ${ }^{74}$ particularly where shared material practices could foster shared histories. From this perspective the cultural landscape is no longer limited to metaphor, but directly implicated in the choices that people make. 
Oliver, J. \& Edwald, Á (in press). Between islands of ethnicity and shared landscapes: rethinking settler society, cultural landscapes and the study of the Canadian west'. Cultural Geographies.

DOI: $10.1177 / 1474474014561576$

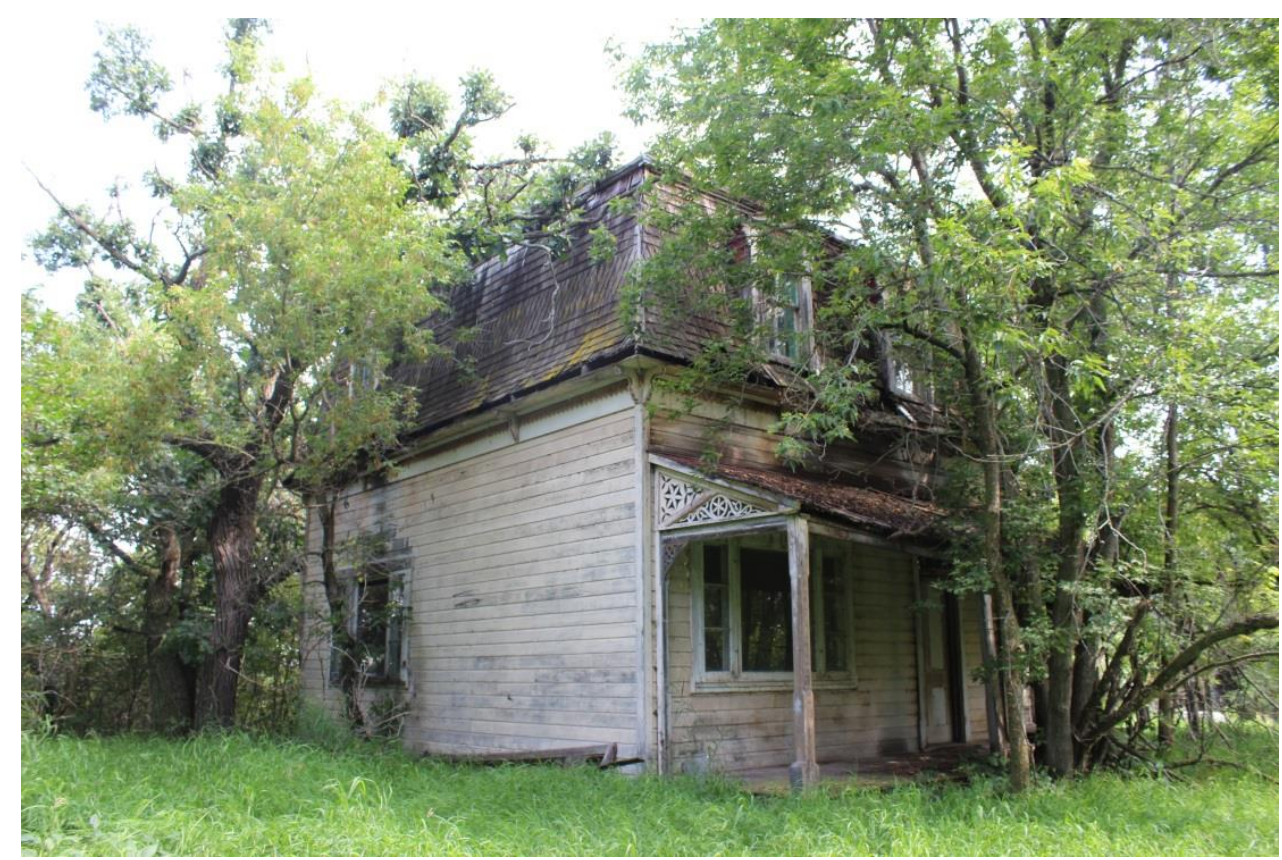

Figure 4. Shared histories, materialized. The figure shows the remains of Sigurdur Christopherson's house on his farm NE-10-6-14, featuring a Second Empire-influenced mansard roof. Similar dwellings can still be observed within the Rural Municipality of Argyle. [Photo: J. Oliver].

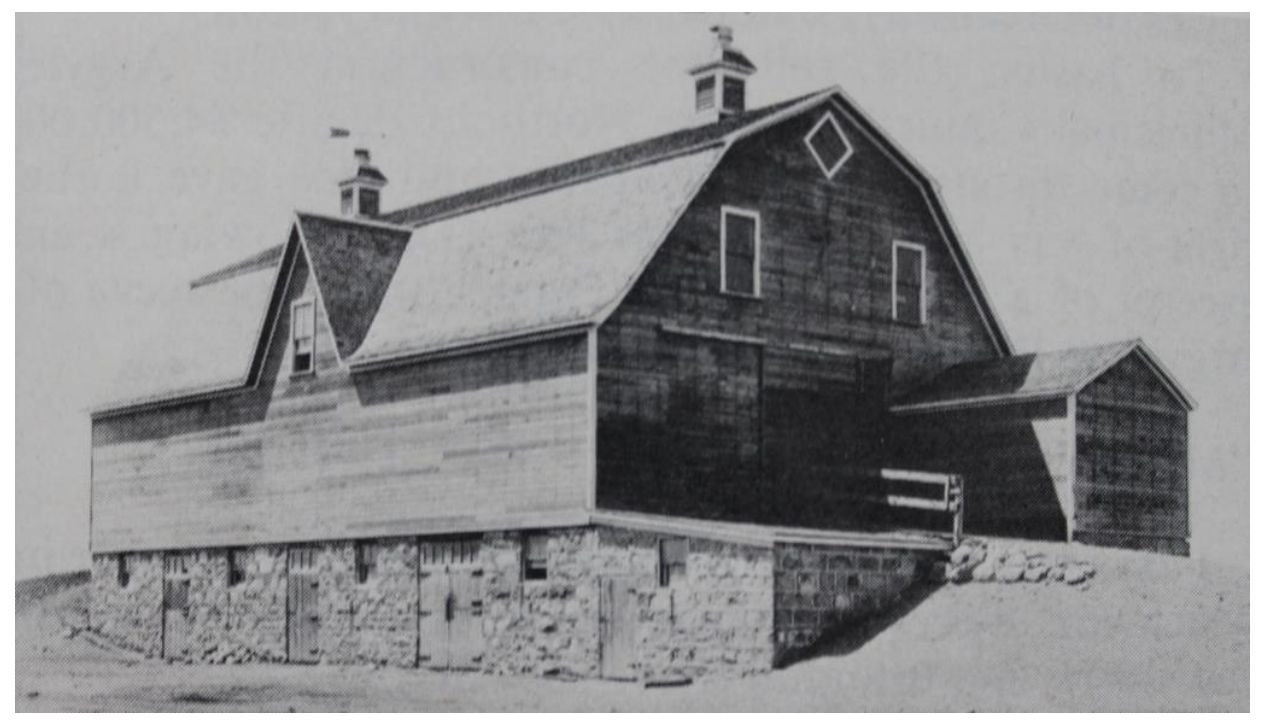

Figure 5. The figure shows Icelandic migrant, Arni Sveinsson's 'Southern Ontarian' style barn built in

1902 on his farm N 23-6-14W (From Hanks et al. Come into our Heritage. R.M. of Argyle 1882-1982, 1982, 28). Ontarian migrants moved to the Prairie Provinces in great numbers, introducing 
Oliver, J. \& Edwald, Á (in press). Between islands of ethnicity and shared landscapes: rethinking settler society, cultural landscapes and the study of the Canadian west'. Cultural Geographies.

DOI: $10.1177 / 1474474014561576$

architecture that was both fashionable and suited to the demands of modern livestock farming in undulating country.

\section{Comparative and multi-sited research}

A good deal of current prairie scholarship tends to focus on localized studies of block settlements. Starting with a given ethnic community has a number of advantages, such as the mastering of different data sets and a narrower analytical frame from which to reveal the contingencies and ambiguity of place. However, there are also distinct disadvantages; notably challenges in contextualizing the relative merits of such conclusions within the larger world of possibilities. At worst, one finds that studies reach similar findings, especially when highlighting ethnic survival. In such cases conclusions chime with like-minded terms: persistence, coherence and vitality are common interpretations. What we advocate here is a more nuanced approach, which retains the potential of localized scales of analysis, but which underlines the methodological importance of micro-comparative studies and crucially multi-sited research.

The potential of new methodological horizons is starting to be recognized in recent research. Making a distinct break with the generalizing assessments of ethnic identity characteristic of earlier decades, Loewen's work on two distinct Mennonite communities in Manitoba and Kansas, points towards the value of micro-scale comparative research in eliciting disjunctures of settler experience. In disputing any single historical trajectory, Loewen argues for a multi-stranded narrative, which shows how ethnicity, religion and inherited social practices were resolved locally - a necessity given the varying influences that communities faced. Desire lines, power and access to resources were not evenly distributed, resulting in contours of historical experience that do not sit easily alongside grander narratives. ${ }^{75}$ 
Oliver, J. \& Edwald, Á (in press). Between islands of ethnicity and shared landscapes: rethinking settler society, cultural landscapes and the study of the Canadian west'. Cultural Geographies.

DOI: $10.1177 / 1474474014561576$

But what is more, if we are to think critically about the potential creation of shared landscapes, then we must also think more holistically about ethnic settlements. Like a metaphor for the field more generally, the cartography of ethnic scholarship has tended to focus our attention on the spaces within the boundaries of block settlements portrayed so boldly on maps; but for most people life was played out across a variety of settings, increasingly shaped by the spatial and temporal demands of market-based capitalism and the evolving organs of the state. ${ }^{76}$ Even those most discriminated against in society were not tied to their farms: they were attracted to opportunities that took them farther afield, entangling them seasonally within the varied networks of wage-labour economy, cooperatives, trade centres, as well as state-sponsored institutions. ${ }^{77}$ Furthermore, most areas of ethnic settlement were hardly homogeneous: they incorporated and bordered the settlements of a range of people with different customs and creeds, creating opportunities for encounter, collaboration, and mutual understanding. It is within these spaces of interaction that we must begin to seriously consider the historical moments where openings in the fence lines of ethnic history provided the means for shared histories to proliferate.

\section{Conclusion}

In this paper we have sought to characterize a very broad field. In common with other studies of North American settler society, prairie scholarship on the cultural landscape of western Canada has followed themes central to the study of cultural continuity and change, including assimilation, cultural revivalism and transnationalism. At the same time, our review also reveals a scholarly landscape of increasing eclecticism and complementarity that is sometimes difficult to appreciate when disciplinary barriers obscure the view: if recent scholarship can be taken as indicative of future trends, theories of place and space are becoming as central to the study of the cultural landscape as are the traditional emphasis on folk traditions. And though the contribution of archaeology has yet to be fully appreciated by other disciplines, we are confident it has come of age. 
Oliver, J. \& Edwald, Á (in press). Between islands of ethnicity and shared landscapes: rethinking settler society, cultural landscapes and the study of the Canadian west'. Cultural Geographies.

DOI: $10.1177 / 1474474014561576$

Our review also highlights a certain longstanding commitment to what might be called an ethnic paradigm. While an early fixation on the Other can be explained away to Anglo-Canadian ethnocentrism, the growing emphasis on multiculturalism from the early twentieth century onward has encouraged continued interest in ethnicity, ${ }^{78}$ with recent work exploring the increasing flexibility of its boundaries. Far fewer, however, have looked beyond the ethnic prioritization of the cultural landscape. To be sure many have pointed out the problems with viewing block settlements as homogeneous cultural islands, but the tendency to focuses squarely on particular named groups limits our interpretation of culture to a form of 'identity history', which hardly captures the complex web of overlapping and relational idioms of affiliation, belonging or connectedness, which characterized this busy and heterogeneous world.

We propose a way forward to the study of culture not limited to Old World labels, but one born through the interactive and iterative process of living and working in a new land, where the coming together of new people, objects and ideas created opportunities not only for registering difference, but as we have argued, for creating common ground. Through focusing on relationships rather than boundaries, we may begin to recognize the possibilities of shared landscapes built on the back of material practices that sought solutions to the shared problems of agrarian life. The objective should be to move from a position concerned with the nature of ethnicity to one that accepts that ethnicity is not the only organizing principle of social and cultural history, even though a disproportionately large archive of scholarship on the subject suggests otherwise. The implications of such an approach are not to deny ethnic boundaries, or the histories of discrimination that they could foster (and here we must also include indigenous peoples), but rather to recognize, as Friesen and Loewen do, that ethnicity passes through moments of 'relevancy and irrelevancy'. ${ }^{79}$ The future of the cultural landscape is a field that has been little tilled: by lifting the veil of self-evidence that has settled on it, we suggest there is room to produce a richer, more lived-sense of the shifting issues and tensions that gave definition to society within different times and places. 
Oliver, J. \& Edwald, Á (in press). Between islands of ethnicity and shared landscapes: rethinking settler society, cultural landscapes and the study of the Canadian west'. Cultural Geographies.

DOI: $10.1177 / 1474474014561576$

\section{Funding}

The research for this article was funded by a Leverhulme Trust Project Grant (RPG-2012-653).

\section{Acknowledgements}

This article was written in connection with the project 'European Migrant Landscapes and Intercultural Relations in Western Canada' (Principal Investigator J. Oliver), based at the University of Aberdeen, Scotland. Help with sources was provided by individuals at a number of institutions. In particular we would like to thank Marjory Harper at the University of Aberdeen and Dr Birna Bjarndadottir and other staff at the Department of Icelandic Languages and Literature, University of Manitoba. Field work was carried out in both the Interlake region and southwestern Manitoba. Thanks go in particular to our hosts in Gimli, Elva Simundsson and Jerry Jonason for their excellent hospitality. Earlier incarnations of some of the ideas presented here have benefited from comments received from Audrey Horning, Jim Symonds and Kurt Jordon. We are particularly grateful to Gerald Friesen and Ana Jorge for extensive feedback on earlier drafts. Finally, we would like to thank our peer reviewers for their clear-eyed assessment and useful suggestions, which we hope have helped to sharpen the final product. All errors are our own.

\section{Author biographies}

Jeff Oliver is Senior Lecturer in the Department of Archaeology at the University of Aberdeen, Scotland. Among other interests, he researches the social asymmetries of colonial history, particularly in terms of their connections to landscape. He is the author of Landscapes and Social Transformations on the Northwest Coast: Colonial Encounters in the Fraser Valley (University of Arizona Press, 2010). Recently he co-edited (with Neil Curtis) a special issue of the journal Historical Archaeology on the Contemporary and Historical Archaeology of the Northern World to be published later this year. 
Oliver, J. \& Edwald, Á (in press). Between islands of ethnicity and shared landscapes: rethinking settler society, cultural landscapes and the study of the Canadian west'. Cultural Geographies.

DOI: $\underline{10.1177 / 1474474014561576}$

Ágústa Edwald is Post Doctoral Research Fellow at the Department of Archaeology at the University

of Aberdeen, Scotland. Ágústa completed her PhD degree at the same department in 2012 on the emigration from Iceland to Canada in the late 19th Century. Ágústa's research focuses on materiality and identity, modernity, skills and tradition within the context of later historical archaeology particularly in Iceland and the North.

\footnotetext{
1 J.W. Bennett and S.B. Kohl, Settling the Canadian-American West, 1890-1915 (Lincoln and London, University of Nebraska Press, 1995); R. Loewen, Ethnic Farm Culture in Western Canada. Canada's Ethnic Group Series Booklet No 29 (Ottawa, The Canadian Historical Association, 2002).

${ }^{2}$ A good deal of postcolonial scholarship has dealt with the social asymmetries and cultural entanglements produced in the context of colonial resettlement. For ways into this burgeoning literature with reference to Western Canada see: S. Carter, Aboriginal People and Colonizers of Western Canada (Toronto, University of Toronto Press, 1999); C. Harris, Making Native Space: Colonialism, Resistance, and Reserves in British Columbia (Vancouver, UBC Press, 2002); J. Oliver, Landscapes and Social Transformations on the Northwest Coast: Colonial Encounters in the Fraser Valley (Tucson, University of Arizona Press, 2010); F. Tough, 'As Their Natural Resources Fail': Native Peoples and the Economic History of Northern Manitoba, 1870-1930 (Vancouver, UBC Press, 1996).

${ }^{3}$ D. Doroszenko, 'Exploration, Exploitation, Expansion and Settlement. Historical Archaeology in Canada', in T. Majewski and D. Gaimster eds, International Handbook of Historical Archaeology (New York, Springer, 2009), pp. 507-524; G. Friesen and R. Loewen, 'Romantics, Pluralists, Postmodernists: Writing Ethnic History in Prairie Canada', in G. Friesen River Road: Essays on Manitoba and Prairie History (Winnipeg, University of Manitoba Press, 1996), pp. 183-196; F. lacovetta, The Writing of English Canadian Immigrant History. Canada's Ethnic Group Series Booklet No. 22 (Ottawa, The Canadian Historical Association, 1997); Loewen, Ethnic Farm Culture in Western Canada; R. Loewen, 'Beyond the Monolith of Modernity: New Trends in Immigrant and Ethnic Rural History', Agricultural History 81(2) (2007), pp. 204-227; H. Palmer, 'Canadian Immigration and Ethnic History in the 1970s and 1980s', International Migration Review 15(3) (1981), pp. 471-501.

${ }^{4}$ R. Brubaker and F. Cooper, 'Beyond "Identity"', Theory and Society 29 (2001), pp. 1-47; C. Hillerdal, People in Between: Ethnicity and Material Identity - a New Approach to Deconstructed Concepts, Occasional Papers in Archaeology 50 (Uppsala, Uppsala University, 2009); R. Jenkins, Social Identity, $2^{\text {nd }}$ Edition (London, Routledge, 2005); S. Jones, The Archaeology of Ethnicity: Constructing Identities in the Past and Present (London, Routledge, 1997).

${ }^{5}$ For example see J.C. Lehr, 'The Ukrainian Sacred Landscape: A Metaphor of Survival and Acculturation', Material History Bulletin 29 (1989), pp. 3-11.

${ }^{6}$ S. Bellay, Pluralism and Race/Ethnic Relations in Canadian Social Science, 1880-1939, Unpublished Ph.D. (Winnipeg, Department of History, University of Manitoba, 2001).

${ }^{7}$ F.J. Turner, The Significance of the Frontier in American History, Annual Report of the American Historical Association, 1893 (1894), p. 227.

${ }^{8}$ W. H. Hingston, The Climate of Canada and its Relation to Life and Health (Montreal, Dawson Brothers Publishers, 1884).

9 J.S. Woodsworth, Strangers Within Our Gates (Toronto, University of Toronto Press, 1972 [1909]); R.G. MacBeth, Our Task in Canada (Toronto, The Westminster Co. Limited, 1912); A. Hawkes, The Birthright. A Search for the Canadian and the Larger Loyalty (Toronto, J.M. Dent \& Sons Itd., 1919).

${ }^{10}$ Woodsworth, Strangers Within Our Gates, p. 167.

${ }^{11}$ S.D. Clark, 'Sociology in Canada: An Historical Overview', Canadian Journal of Sociology 1(2) (1975), pp. 225234.

12 For example see R.E. Park and H.A. Miller, Old World Traits Transplanted (New York, Harper \& Brothers, 1921); O. Handlin, The Uprooted (Boston, Little Brown, 1951); O.D. Duncan and S. Leieberson, 'Ethnic Segregation and Assimilation', American Journal of Sociology 64(6) (1959), pp. 364-374; S. Persons, Ethnic Studies at Chicago 1905-1945 (Chicago, University of Illinois Press, 1987).
} 
Oliver, J. \& Edwald, Á (in press). Between islands of ethnicity and shared landscapes: rethinking settler society, cultural landscapes and the study of the Canadian west'. Cultural Geographies.

DOI: $10.1177 / 1474474014561576$

${ }^{13}$ R.England, The Central European Immigrant in Canada (Toronto, Macmillan, 1929).

${ }^{14}$ C.A. Dawson, Group Settlement: Ethnic Communities in Western Canada (Toronto, The Macmillan Company of Canada Limited, 1936).

${ }^{15}$ M.M. Gordon, Assimilation in American Life. The Role of Race, Religion, and National Origins (New York, Oxford University Press, 1964); R.J. Vecoli, 'Contadini in Chicago: A Critique of the Uprooted', The Journal of American History 51(3) (1964), pp. 404-417; R. Breton, 'Institutional Completeness of Immigrant Ethnic Communities', in J.G. Reitz, ed., Ethnic Relations in Canada: Institutional Dynamics: Raymond Breton (Montreal, McGill University Press 2005 [1964]), pp. 169-183.

${ }^{16}$ Gordon, Assimilation in American Life.

${ }^{17}$ Breton, Institutional Completeness.

${ }^{18}$ For research on the Ukrainians see P. Yuzyk, The Ukrainians of Manitoba. A Social History (Toronto, University of Toronto Press, 1953); on the Jews see A. Chiel, The Jews in Manitoba. A Social History (Toronto, University of Toronto Press, 1961); on the Poles see V. Turek, The Poles in Manitoba (Toronto, Polish Alliance Press, 1967).

${ }^{19}$ A.B. Anderson, 'Ethnic Identity in Saskatchewan Block Settlements: A Sociological Appraisal', in H. Palmer, ed., The Settlement of the West (Calgary, University of Calgary Comprint Publishing Company, 1977), p. 223.

20 J. Dahlie, 'Scandinavian Experiences on the Prairies, 1890-1920. The Frederiksens of Nokomis', in H. Palmer, ed., The Settlement of the West (Calgary, The University of Calgary Comprint Publishing Company, 1977), pp. 102-113.

21 J.K. Vladimir, Early Ukrainian Settlements in Canada, 1895-1900: Dr. Josef Oleskow's Role in the Settlement of the Canadian Northwest (Toronto, University of Toronto Press, 1964); J.D. Wilson, 'Ethnic Studies and Multiculturalism in Canada', American Studies in Scandinavia 12 (1980), pp. 17-26; lacovetta, English Canadian Immigrant History.

${ }^{22}$ See in particular Bennett and Kohl, Settling the Canadian-American West.

${ }^{23}$ See for example B. Trigger, A History of Archaeological Thought (Cambridge, Cambridge University Press, 1989), p. 340.

${ }^{24}$ R.J.F. Day, Multiculturalism and the History of Canadian Diversity (Toronto, University of Toronto Press, 2000); O. Zunz, 'American History and the Changing Meaning of Assimilation', Journal of American Ethnic History 4(2) (1985), pp. 53-72.

${ }^{25}$ R. Lowen, 'The Monolith of Modernity', p. 209; O.Zunz, 'The Changing Meaning of Assimilation'.

${ }^{26}$ On the history of ethnohistory see M. Harkin, Ethnohistory's Ethnohistory: Creating a Discipline from the Ground up. Social Science History 34(2) (2010), pp. 113-114.

${ }^{27}$ For research on the Doukhobours see G. Woodcock and I. Avakumovic, The Doukhobours (Oxford, Oxford University Press, 1968); on the Hutterites see J.A. Hostetler, Hutterite Society (Baltimore, John Hopkins University Press, 1974); on the Mennonites see F. Epp, The Mennonites in Canada, 1786-1920 (Toronto, MacMillan, 1974); on the Scots see M. Harper, 'Crofter Colonists in Canada: An Experiment in Empire Settlement', Northern Scotland 14 (1994), pp. 69-108.

${ }^{28}$ R. L. Hinther and J. Mochoruk, eds, Re-Imagining Ukrainian-Canadians. History, Politics and Identity (Toronto, University of Toronto Press, 2011). For examples of this literature see L. Luciuk and S.M. Hryniuk, eds, Canada's Ukrainians: Negotiating an Identity (Toronto, Ukrainian Canadian Centennial Committee in association with University of Toronto Press, 1991); O.T. Martynowych, Ukrainians in Canada: The Formative Period 1891-1924. Edmonton: Canadian Institute of Ukrainian Studies Press, 1991); F. Swyripa, Wedded to the Cause: Ukrainian-Canadian Women and Ethnic Identity 1891-1991. Toronto: University of Toronto Press, 1993).

${ }^{29}$ Swyripa, Wedded to the Cause.

${ }^{30}$ For research on settlement patterns see Y. Katz and J.C. Lehr, The Last Best West. Essays on the Historical Geography of the Canadian Prairies (Jerusalem, Magnes Press Hebrew University, 1999); D.A. McQuillan, 'Territory and Ethnic Identity: Some New Measures of an Old Theme in the Cultural Geography of the United States', in J.R. Gibson, ed., European Settlement and Development in North America: Essays on Geographical Change in Honour and Memory of Andrew Hill Clark (Toronto, University of Toronto Press, 1978), pp. 136-169. On farm layouts see W.J. Carlyle, 'Farm Layouts in Manitoba', The Canadian Geographer 27(1), (1983), pp. 1734. On cemetery landscapes see J.C. Lehr, 'The Ukrainian Sacred Landscape'. On folk housing see A. Noble, ed., To Build in a New Land. Ethnic Landscapes in North America (Baltimore and London, The John Hopkins 
Oliver, J. \& Edwald, Á (in press). Between islands of ethnicity and shared landscapes: rethinking settler society, cultural landscapes and the study of the Canadian west'. Cultural Geographies.

DOI: $10.1177 / 1474474014561576$

University Press, 1992); E.M. Ledohowski and D.K. Butterfield, Architectural Heritage in the Eastern Interlake Planning District (Winnipeg, Historic Resources Branch, 1983).

31 J.C. Lehr, 'The Ukrainian Sacred Landscape', p. 8.

${ }^{32}$ Y. Katz and J.C. Lehr, The Last Best West.

33 J. Deetz, In Small Things Forgotten: The Archaeology of Early American Life (Garden City, NY, Anchor Books, 1977).

${ }^{34}$ For example see M. Kennedy, 'Canada', in C. Orser, ed., Encyclopedia of Historical Archaeology (London and New York, Routledge, 2002), pp. 86-87; L. Uunila, F. Miller, E. Rohatensky and R. Cooley, Motherwell Homestead. National Historic Site of Canada (Canada, Parks Canada, 2009).

${ }^{35}$ For research on the Metis see D. Burley, G. Horsfall and J. Brandon, Structural Considerations of Métis Ethnicity: An Archaeological, Architectural and Historical Study (Vermillion, University of South Dakota Press, 1992); on the Doukhobors see M. Brooks, Public Archaeology with a Doukhobor Descendant Community. Unpublished MA Thesis (Saskatoon, Department of Archaeology and Anthropology, University of Saskatchewan, 2005); S.C. Kozakavich, A state of Change. An Historical Archaeology of Doukhobor Identity at Kirilovka Village Site (FcNS-1), Unpublished MA Thesis (Saskatoon, Department of Archaeology and Anthropology, University of Saskatchewan, 1998); S.C. Kozakavich, 'Identity and Communalism at Kirilovka Village Site', Historical Archaeology, 40(1) (2006), pp. 119-132; on the Mennonites see R. Sawatzky, The Control of Social Space in Mennonite Housebarns of Manitoba, 1874-1940, Unpublished Ph.D. Thesis (Vancouver, Department of Archaeology, Simon Fraser University, 2005); R. Sawatzky, 'Ideology, Space and Social Control: The Russian-Mennonite Family in Historic Manitoban Architecture', Journal of Mennonite Studies 26 (2008), pp. 95-110; on Ukrainian research see discussion in Kennedy, 'Canada'; on English settlement see K.M. Enns-Kavanagh, Cannington Manor, An Early Settlement Community in Southeastern Saskatchewan, Unpublished MA Thesis (Saskatoon, Department of Archaeology and Anthropology, 2002).

${ }^{36}$ M. Kennedy, 'Homestead Archaeology in the Saskatoon Region', Saskatchewan Archaeological Society Newsletter 28(4) (2007), pp. 105-108.

${ }^{37}$ The use of Bourdieu's concept of habitus is characteristic of the more theoretically engaged research carried out by historical archaeologists. While there is an argument for connecting this body of work with the ambivalences of the cultural turn, historical archaeologists have tended to focus on the routine and repetitive aspects of habitus, meaning they have been more interested in the maintenance or reproduction of cultural forms than their transformation. For habitus see P. Bourdieu, Outline of a Theory of Practice, (Cambridge, Cambridge University Press, 1977).

${ }^{38}$ S.C. Kozakavich, A state of Change, pp. 207; see also S.C. Kozakavich, 'Identity and Communalism at Kirilovka Village Site'.

${ }^{39}$ C. Harzig and D. Hoerder, 'Transnationalism and the Age of Mass Migration, 1880s to 1920s', in V. Satzewich and L. Wong, eds, Transnational Identities and Practices in Canada (Vancouver, UBC Press, 2006), p. 50.

40 J.C. Lehr, Community and Frontier: A Ukrainian Settlement in the Canadian Parkland (Winnipeg, University of Manitoba Press, 2011).

${ }^{41}$ E. Hobsbawm and T. Ranger, eds, The Invention of Tradition (Cambridge, Cambridge University Press, 1983).

${ }^{42}$ B. Anderson, Imagined Communities: Reflections on the Origin and Spread of Nationalism (London and New York, Verso, 1991).

${ }^{43}$ F. Swyripa, Storied Landscapes. Ethno-Religious Identity and the Canadian Prairies (Winnipeg, University of Manitoba Press, 2010); R. Loewen and G. Friesen, Immigrants in Prairie Cities. Ethnic Diversity in TwentiethCentury Canada (Toronto, University of Toronto Press, 2009).

${ }^{44}$ Syripa, Storied Landscapes. See also L.K. Bertram, 'Public Spectacles, Private Narratives: Canadian Heritage Campaigns, Maternal Trauma and the Rise of the Koffort (Trunk) in Icelandic-Canadian Popular Memory', Material Culture Review/Revue de la Culture Matérielle 71 (2010), pp. 39-53.

${ }^{45}$ lacovetta, The Writing of English Canadian Immigrant History; Loewen, Ethnic Farm Culture in Western Canada; R. Perin, 'National Histories and Ethnic History in Canada', Cahiers de recherché Sociologique 20 (1993), pp. 113-128.

${ }^{46}$ Loewen and Friesen, Immigrants in Prairie Cities.

${ }^{47}$ On Ukrainian-Polish relations see F. Strambrook and S. Hryniuk, 'Who Were They Really? Reflections on East European Immigrants to Manitoba Before 1914', in G.P. Marchildion, ed., Immigration and Settlement, 1870 1939 (Regina, University of Regina and Canadian Plains Research Centre, 2009 (2000), pp. 457-481; On Icelandic-Indigenous relations see R. C. Eyford, Quarantined Within a New Colonial Order: The 1876-1877 Lake 
Oliver, J. \& Edwald, Á (in press). Between islands of ethnicity and shared landscapes: rethinking settler society, cultural landscapes and the study of the Canadian west'. Cultural Geographies.

DOI: $10.1177 / 1474474014561576$

Winnipeg Smallpox Epidemic. Journal of the Canadian Historical Association 17(1) (2006), pp. 55-78. For an intriguing story about the sharing of fishing technology between newcomers and natives see Á. Edwald, Fishing for Modernity: How Material Relationships can Mediate Tensions in an Immigrant Community, The Case of the Icelandic Emigration to Canada. International Journal of Historical Archaeology 16 (2012), pp. 529-546.

${ }^{48}$ N.B. Dirks, Colonialism and Culture (Ann Arbour, University of Michigan Press, 1992); C. Gosden, Archaeology and Colonialism. Culture Contact from 5000 BC to the Present (Cambridge, Cambridge University Press, 2004). ${ }^{49}$ D. Pearson, 'Theorizing Citizenship in British Settler Societies', Ethnic and Racial Studies, 25(6), (2002), pp. 102.

${ }^{50}$ For a discussion of the construction of Ukrainian identities in Canada see L. Luciuk and S. Hryniuk (eds) Canada's Ukrainians: Negotiating an Identity (Toronto, Ukrainian Canadian Centennial Committee in association with University of Toronto Press, 1991).

$51 \mathrm{~J}$. Comaroff and J. Comaroff, Ethnography and the historical imagination (Boulder, CO., Westview Press, 1992), pp. 57.

${ }^{52}$ On ethnographic survey see Dawson, 'Group Settlement'. On colonial boundary making see Dirks, Colonialism and Culture. Examples of these processes can be found in K. Brealey, Mapping them 'out': EuroCanadian cartography and the appropriation of the Nuxalk and Ts'ilhqot'in First Nations' territories, 17931916. Canadian Geographer 39 (1995), pp. 140-156; B. Thom, 'The Paradox of Boundaries in Coast Salish Territories', Cultural Geographies 16(2) (2009), pp. 179-205; J. Oliver, Landscapes and Social Transformations on the Northwest Coast: Colonial Encounters in the Fraser Valley (Tucson, University of Arizona Press, 2010), pp 163-200.

${ }^{53}$ Day, Multiculturalism. See also G. Hannah, Governmentality and the Mastery of Territory in NineteenthCentury America (Cambridge, Cambridge University Press, 2000)

${ }^{54}$ Day, Multiculturalism, p. 165.

${ }^{55}$ Brubaker and Cooper, 'Beyond "Identity"', p. 2.

${ }^{56}$ lacovetta, The Writing of English Canadian Immigrant History, p. 8.

${ }^{57}$ Loewen, Ethnic Farm Culture in Western Canada, p. 13.

58 M. Strathern, The Gender of the Gift: Problems with Women and Problems with Society in Melanesia (Berkely, University of California Press, 1988).

${ }^{59}$ For detail on this argument see D. Massey, 'Landscape as a Provocation. Reflections on Moving Mountains', Journal of Material Culture 11(1/2), (2006), p 40.

${ }^{60}$ The example is cited in P. J. Giffin and G. Friesen, Rural Life: Portraits of the Prairie Town, 1946 (Winnipeg, University of Manitoba Press, 2004). We would like to thank Gerald Friesen for shedding further light on this example. As indicated to us in earlier comments about this article, Friesen writes the point I discovered in going to Rossburn is that the line, while sharp in one moment or one speech, was also blurred and often, indeed, erased [in another]'.

${ }^{61}$ R. Harrison, Shared Landscapes: Archaeologies of Attachment and the Pastoral Industry in New South Wales (Sydney, University of New South Wales Press, 2004). The concept of shared histories is traced back to the work of Australian historian, Peter Read. See P. Read, Belonging: Australians, Place and Aboriginal Ownership (Cambridge, Cambridge University Press, 2000).

62 J. Lave and E. Wenger, Situated Learning: Legitimate Peripheral Participation (Cambridge, Cambridge University Press, 1991), pp. 97-98.

${ }^{63}$ E. Wenger, Communities of Practice: Learning, Meaning, and Identity (Cambridge, Cambridge University Press, 1998). A number of other helpful studies have drawn on the concept. See in particular: P. Prior, Are Communities of Practice Really an Alternative to Discourse Communities? Paper Presented at the 2003 American Association of Applied Linguistics (AAAL) Conference. Available at

http://www.researchgate.net/publication/228784036 Are communities of practice really an alternative $t$ o discourse communities; K. E. Sassaman and W. Rudolphi, Communities of Practice in the Early Pottery Traditions of the American Southeast. Journal of Anthropological Research 57(4) (2001), pp. 407-425.

$64 \mathrm{~J}$. Clayton, 'Thinking Spatially: Towards an Everyday Understanding of Inter-Ethnic Relations', Social and Cultural Geography 10(4) (2009), pp. 481-498; J. Oliver, Native-Lived Colonialism and the Agency of Life Projects: A View from the Northwest Coast, in N. Ferris, R. Harrison and M. Wilcox, eds, Rethinking Colonial Pasts Through Archaeology (Oxford, Oxford University Press, 2014).

${ }^{65}$ Kozakavich, Identity and Communalism, p. 125. 
Oliver, J. \& Edwald, Á (in press). Between islands of ethnicity and shared landscapes: rethinking settler society, cultural landscapes and the study of the Canadian west'. Cultural Geographies.

DOI: $10.1177 / 1474474014561576$

${ }^{66}$ A good deal of research in this area has been initially influenced by Afred Gell's work; see A. Gell, Art and Agency: An Anthropological Theory (Oxford, Clarendon, 1998).

${ }^{67}$ B. Olsen, Material Culture After Text: Remembering Things, Norwegian Archaeological Review 36 (2003), pp. 87-104; C. Philo, 'More Words, More Worlds: Reflections on the 'Cultural Turn' and Human Geography', in I Cook, D. Crouch, S. Naylor and J.R. Ryan, eds, Cultural Turns/Geographical Turns (Harlow, Pearson Education Limited, 2000), pp. 26-53; T. Bennett and P. Joyce, eds, Material Powers. Cultural Studies, History and the Material Turn (London and New York, Routledge, 2010).

${ }^{68}$ H. Green, 'Cultural History and the Material(s) Turn', Cultural History 1(1) (2012), pp. 61-82; D. Hicks, 'The Material-Cultural Turn: Event and Effect', in D. Hicks and M. Beaudry, eds, Material Culture Studies (Oxford, Oxford University Press, 2010), pp. 25-98.

${ }^{69}$ B. Bender, 'Time and Landscape', Current Anthropology 43(Supplement) (2002), pp S103-S112

${ }^{70}$ Ledohowski and Butterfield, Architectural Heritage; Noble, To Build in a New Land.

${ }^{71} \mathrm{~J}$. Oliver and A. Edwald, European Cultural Landscapes in Manitoba - An Interethnic Perspective. Paper Presented at the Society of Historical Archaeology conference (Quebec, 2014).

${ }^{72}$ I. Hodder, Entangled: An Archaeology of the Relationships Between Humans and Things (Malden, MA, John Wiley and Sons, 2012).

${ }^{73}$ C. Gosden, 'What Do Objects Want?', Journal of Archaeological Method and Theory 12(3) (2005), p. 194.

${ }^{74}$ Hillerdal, People in Between, p. 8.

${ }^{75}$ R. Loewen, Diaspora in the Countryside: Two Mennonite Communities and Mid-Twentieth Century Rural Disjuncture (Toronto, University of Toronto Press, 2006).

${ }^{76}$ We borrow this point from Lightfoot who has suggested a similar comparative approach; see K. Lightfoot, 'Missions, Furs, Gold, and Manifest Destiny: Rethinking an Archaeology of Colonialism for Western North America, in M. Hall and S. Silliman', eds, Historical Archaeology (Oxford, Blackwell Publishing, 2006), pp. 272 292.

77 See for example Lehr, Community and Frontier, p.53.

${ }^{78}$ For example, Richard Day, Multiculturalism, p. 151, identifies the emergence of the Canadian Mosaic metaphor to the 1920's with the work of K. Foster, Our Canadian Mosaic (Toronto, YWCA, 1926).

${ }^{79}$ Friesen and Loewen, 'Romantics, Pluralists, Postmodernists', p. 193. 